\begin{tabular}{l|c|c|}
\hline DE & DE GRUYTER \\
$\mathrm{G}$ & EPEN & ECONOMIC THEMES (2017) 55(1): 105-120 \\
\hline
\end{tabular}

\title{
EFFECTS OF REMITTANCES ON RURAL AND REGIONAL POVERTY IN THE REPUBLIC OF SERBIA
}

\section{Drinka Peković}

Higher School of Professional Business Studies, Novi Sad, Serbia

凶drinkapekovic@yahoo.com

UDC

314.745.3-

054.72:336.

$741.1(497.1$

1)

Review

paper

\begin{abstract}
This paper examines an effect the remittances have on poverty alleviation of rural households and regions in which exist a large number of the emigrants among population. Remittances represent a significant part of additional income of the household mostly used for consumption and improvement of the living standard. Using data from Living Standards Measurement Survey 2007, an impact of the remittances on the poverty index, depth of poverty and poverty severity in the Republic of Serbia is estimated. Due to limitation of data, counterfactual household consumption is estimated in conditions of remittances absence, where the last is treated as exogenous transfer of money. The results show that remittances have a larger impact to poverty of rural households, especially to the depth and severity of poverty. According to the regions, remittances have the largest impact to the poverty level in East Serbia, but these effects on poverty depth and severity are not statistically significant. The smallest changes in the depth and severity of poverty are noticed in Sumadija.
\end{abstract}

Received: Keywords: migration, remittances, poverty, the Republic of Serbia.

21.12.2016.

Accepted:

JEL classification: F24, I30

\section{Introduction}

International migration labour flows have a significant role in economic relations between developed countries and developing countries. According to data of the UN, app. 3 percent of the world population lives and works out of a birth country. Emigration labour flows cause many positive and negative effects to the labour market and economy of countries. Inflow of remittances sent by the emigrantsworkers to their families is often underlined as one of positive effects of emigration. Ten recipient countries of the largest amount of remittances are developing countries. Beside of foreign direct investments, remittances become 
very significant and relative stable source of emigration countries' economy financing. In recent years, we may notice an interest in reviewing the role and contribution of the remittances to economic growth and poverty alleviation.

The Republic of Serbia is traditionally an emigration country with relative large Diaspora estimated on 3,9 up to 4,2 million of people. According to results of last Census from 2011, the share of emigrants in total population of the Republic of Serbia amounts 4.13 percent. One should bear in mind that Census did not cover the persons who migrated in the context of family migration. According to the size of labour emigration flows, some regions stand out as high emigrational (South and East Serbia) (Pejin-Stokic \& Grecic, 2012).

According to the World Bank, the Republic of Serbia is among 20 countries being the largest receivers of remittances (World Bank, 2011). At the level of households, remittances are a substantial source of an additional income usually spent by the households for consumption and improvement of the living standard. The number of remittance receiving households and amount of the last are considerably higher in high emigration regions in relation to others. From that reason, a special attention will be paid to the role of remittances in decreasing the poverty in these regions.

The aim of this paper is to examine the remittance effects on rural and regional poverty alleviation in the Republic of Serbia. The hypothesis that remittances as source of income of rural households contributes to reduction of the rural poverty will be tested. In addition, it will be examined whether the effects of the remittances on poverty are higher in high emigration regions compared to other regions.

Upon introduction part, a review of the most considerably theoretical and empirical literature will be given in Section 2. The Section 3 describes data on remittance receiving households in the Republic of Serbia. In Section 4, methodology of researching is discussed. Section 5 presents empirical results. Section 6 concludes.

\section{Literature Review}

There are several empirical studies striving to estimate interdependence between remittances and poverty. One of the reasons is a lack of quality and mutually comparable data on poverty in developing countries. Data on international migration and remittances are also limited and not reliable. Official data do not include the remittances flows that are out of formal channels. It is supposed that remittance size data are considerably underestimated. According to MMF estimations, informal flows of remittances in developing counties amount to 10 billion \$ per year (Page \& Plaza, 2006). 
In recent years, studies about effects of remittances on poverty are based on national household's survey data. Using remittances and poverty data for 71 developing countries with low and middle income, Adams and Page (2005) found that remittances have statistically significant impact on poverty measures in developing countries. Ten percent increase of remittances per capita would cause decreasing the number of poor people in total population for 1.8 percent (Adams \& Page, 2005).

Empirical study of UNCTAD used panel data for 77 developing countries for the period 1980-2008. The results showed that remittances have a negative impact to the poverty index but their impact on the depth of poverty is not statistically significant. However, when those developing countries whose share of remittances in GDP is less than 5 percent were omitted, the results showed statistically significant impact of remittances to the poverty measures. The rise of remittances for 10 percent would decrease the poverty index for 3.1 percent and the depth of poverty for 3-5 percent (UNCTAD, 2011).

In countries which economies have a high level of dependence from remittance inflows, the results of empirical studies show the large remittance effect on poverty. Brown and Jimenez (2008) have estimated the impact of remittances on poverty reduction in Fiji and Tonga. Both countries have severe remittance inflows. If the remittance sending has been stopped, the poverty index would be 42.9 percent in Fiji while the current is 34.1 percent. The poverty depth would be increased for 14.6 percent (Brown \& Jimenez, 2008). Biyase (2012) found the similar results estimated the remittances effects in South Africa where poverty index is very high (47.7 percent). Without remittances the poverty index would be 67 percent (Byase, 2012).

In empirical studies of remittances effects on poverty in Guatemala and Ghana, Adams $(2004,2006)$ points that remittances have a larger impact on decreasing of sensitive poverty measures like depth of poverty and poverty severity. In addition, according to results, international remittances have a larger effect on reduction of the poverty severity in Ghana than internal remittances. When the international remittances are included in the household income, the poverty severity decreases for 34.8 percent while the poverty index shows relatively smaller changes (Adams, 2006). Results of study in Guatemala also show that remittances have a larger impact on reducing the poverty severity than the poverty index. One of the reasons is the fact that households in whose income the remittances are significantly represented are in the lowest decile group. In these households, remittances make 60 percent of the total income. A presence of the remittances in the household income reduces the poverty severity for 19.8 percent (Adams, 2004).

Acharya and Leon-Gonzales (2012) also found a larger impact of remittances on reducing poverty depth than poverty index. According the results of their empirical study in Nepal, the excluding of remittances would increase the poverty 
depth for 6.4 percent in 2004 while the poverty index growth would be 4.6 percent (Acharya \& Leon-Gonzales, 2012). Similar effects are found in other empirical studies (Acosta et al., 2008; Bertoli \& Marchetta, 2014).

Emigration is usually concentrated in certain regions of the country and development of migration networks contributes to that fact. In high emigration regions, the remittances amount and number of households that receive them is considerably higher in relation to other regions. Therefore, the effects of the remittances on poverty may be higher in these regions compared to national level. In addition, higher presence of the remittances in household income in rural regions contributes to reduction of the rural poverty. In rural Mexico, remittances represent 13 percent of the household income in average. Although the emigrants mostly come from the households of middle or higher middle level of income, remittances indirectly reduce poverty in rural regions because the households invest a part of remittances into production activities (Rivera, 2005). The ten percent increase in remittance inflows would cause decreasing the poverty index for 1.7 percent in Central West area of Mexico (Taylor et al., 2005).

The poorest area in Albania is Mountain area that is mostly rural. In the period 2002-2005, the largest reduction of the poverty measures were realised in this area. The poverty index was decreased for 42.5 percent, the depth of poverty for 54 percent and the poverty severity for 63 percent, which is doubled in relation to other area. It is considered that remittances are one of the reasons of realised reduction of poverty because the largest growth of the number of remittance receiving households was in Mountain area. An amount of the remittances in this region increased for 50 percent (Hoti, 2009).

Estimating the effects of remittances on the poverty of rural households in Nigeria, Olowa (2013) underlines that the absence of remittances would contribute to the growth of the poverty index for 11.1 percent. Presence of the remittances contributes to reduction of the poverty depth for 5.5 percent while the effect to the poverty severity is missing (Olowa et al., 2013). Bouoiyour and Miftah (2014) estimated that remittance inflows reduced the probability of rural households to be poor for 11.3 percent in average (Bouoiyour \& Miftah, 2014).

The positive effect of remittances to the living standard is present in South Morocco where remittances make 53-59 percent of the income of some households having the emigrants among its members. Their investments into agricultural, construction and other entrepreneurial activities indirectly influence the living standard of other households (de Haas, 2006). De Haas (2006) points that remittance receiving households invest more into equipping residential facilities, also in buying the second and the third house, land, education of children indirectly contributing to the income growth and development of entire area. 
Although the inflow of remittances in the Republic of Serbia is substantial, there are only few studies analysing the role of remittances in poverty reduction. One of the reasons of the lack of a wider research is the fact that statistical data on remittances and poverty measures on household level are very poor and not reliable. Jovicic and Dragutinovic Mitrovic (2006) estimated an impact of remittances on poverty reduction at macroeconomic level. Comparing GDP per capita and remittances, they concluded that remittances, increasing the income level in the Republic of Serbia, represent an important factor of living standard improvement (Jovicic \& Dragutinovic Mitrovic, 2006).

The household level data provide better review into distribution of remittances in certain areas of the country. Detailed micro data on remittances in the Republic of Serbia are limited and scarce. International Organization for Migrations (IOM) conducted in 2007 a research on remittances interviewing 343 households whose members are emigrants in Switzerland in two rural areas of Central and East Serbia (Cuprija and Petrovac na Mlavi). The study gives a profile of emigration households and an analysis of remittance transfer mechanism as well as their use (Petree \& Baruah, 2007).

\section{Data on Remittance Recipients in High Emigration Regions}

The regional distribution of migration flows data show that labour has emigrated at a significant extent from particular regions over the last decades. Emigrants are partially covered by Living Standard Measurement Survey (LSMS) in the Republic of Serbia where for one of the questions about the current presence of household members, the offered answer, among others, is working abroad. According to World's Bank LSMS data for the Republic of Serbia in 2002, the most people working abroad originate from East Serbia (31.3\%), Sumadija (27.5\%) and West Serbia (12.1\%). Within these regions, there is a very high concentration of emigrants in certain districts. The largest number of emigrants in the sample comes from the Branicevo District (24.5\%), Pomoravlje District (9.8\%) and Raska District (8.7\%).

Data on the concentration of emigrants in certain regions can be found in the study of Lenora Suki (2006) where the ratio of the percentage of emigrants in a district to the percentage of the population in that district is used as an indicator. Data indicate that the high emigration regions are East Serbia and Sumadija while in South Serbia the Pcinja District has the highest concentration of emigrants (Table 1). 
Table 1. High emigration districts

\begin{tabular}{|c|c|}
\hline $\begin{array}{l}\text { The ratio of the percentage of } \\
\text { emigrants in a district to the } \\
\text { percentage of the population in that } \\
\text { district }\end{array}$ & District \\
\hline$<0.45$ & Morava, Pirot \\
\hline$<0.6$ and $>0.45$ & $\begin{array}{l}\text { North Backa, Central Banat, North Banat, West } \\
\text { Backa, South Backa, Kolubara, Nisava, } \\
\text { Toplica, Jablanica }\end{array}$ \\
\hline$<0.9$ and $>0.6$ & City of Belgrade, Srem, Sumadija \\
\hline$<1.5$ and $>0.9$ & $\begin{array}{l}\text { South Banat, Macva, Zlatibor, Podunavlje, } \\
\text { Zajecar, Rasina }\end{array}$ \\
\hline$>1.5$ & Branicevo, Bor, Pomoravlje, Raska, Pcinja \\
\hline
\end{tabular}

Source: Suki, L. (2006). Remittances in Serbia and Financial Sector Development: Business Opportunities and Priorities for Investment, p. 30.

The results of 2011 census provide a more complete data about emigration size by region. According to these results, the share of emigrants in total population the Republic of Serbia is 4.13 percent. Vojvodina Province and City of Belgrade have the smallest share emigrants in total population while it is the highest in South and East Serbia (Table 2). According to districts, the highest participation of emigrants in population is in the Branicevo (25.58\%) and Bor District (17\%) as well as the Zlatibor and Raska District in which some municipalities have participation of emigrants in the population of 10-15 percent (Pejin-Stokic \& Grecic, 2012).

Table 2. Number of emigrants by regions

\begin{tabular}{|l|c|c|}
\hline Region & Number of emigrants & $\begin{array}{c}\text { The share of emigrants in } \\
\text { total population (\%) }\end{array}$ \\
\hline City of Belgrade & 41,719 & 2.54 \\
\hline Vojvodina Province & 46,031 & 2.40 \\
\hline Sumadija and West Serbia & 98,274 & 4.88 \\
\hline South and East Serbia & 108,021 & 6.96 \\
\hline the Republic of Serbia & 294,045 & 4.13 \\
\hline
\end{tabular}

Source: Pejin-Stokic, Lj. \& Grecic, V. (2012). Social Impact of Emigration and Ruralurban Migration in Central and Eastern Europe: Final Country Report: Serbia, p. 45

Data on the percentage of poverty in districts of the Republic of Serbia indicate that poverty is the largest problem, among the others, in high emigration areas. The 
Branicevo, Bor and Zajecar as districts with a high participation of emigrants in the population belong to East Serbia region, which is among the poorest regions with a poverty index of 10.1 percent in 2007. In addition, the Zlatibor and Macva Districts belonging to West Serbia region have the poverty rate above the national average. In the period 2002-2007 the largest decrease in the percentage of poor was recorded in Sumadija where high emigration areas like the Pomoravlje, Raska and Rasina Districts are (Statistical Office of the Republic of Serbia, 2008).

Table 3 Distribution of remittance receiving households by regions

\begin{tabular}{|l|c|c|c|c|}
\hline & $\begin{array}{c}\text { Number of } \\
\text { households }\end{array}$ & $\begin{array}{c}\text { Households, } \\
\text { percent }\end{array}$ & $\begin{array}{c}\text { Number of } \\
\text { remittance } \\
\text { receiving } \\
\text { households }\end{array}$ & $\begin{array}{c}\text { Remittance } \\
\text { receiving } \\
\text { households, } \\
\text { percent }\end{array}$ \\
\hline Urban & 2,960 & 53.3 & 108 & 3.65 \\
\hline Rural & 2,597 & 46.7 & 127 & 4.89 \\
\hline City of Belgrade & 921 & 16.6 & 26 & 2.82 \\
\hline Vojvodina Province & 1,388 & 25.0 & 52 & 3.75 \\
\hline Sumadija & 1,032 & 18.6 & 51 & 4.94 \\
\hline West Serbia & 734 & 13.2 & 29 & 3.95 \\
\hline East Serbia & 655 & 11.8 & 51 & 7.79 \\
\hline South-East Serbia & 827 & 14.9 & 26 & 3.14 \\
\hline Total & 5,557 & - & 235 & 4.23 \\
\hline
\end{tabular}

Source: Author's calculation according to LSMS 2007 data

(http://microdata.worldbank.org/index.php/catalog/lsms)

The paper used data about remittance receiving households from the 2007 Living Standards Measurement Survey in the Republic of Serbia that are publicly available on the World Bank website. LSMSs in the Republic of Serbia were conducted in 2002, 2003 and 2007 using the absolute poverty line as the official poverty threshold applying the World Bank methodology. Remittance data were obtained based on amount of help and gifts from friends/relatives from abroad reported by the households. This survey covers 5.557 households from which 235 i.e. 4.23 percent reported received money gifts from abroad.

Distribution of remittance recipients points that remittance receiving households are more prevalent in rural regions than in urban ones. According to regions, the largest share of the remittances receiving households is in East Serbia and Sumadija, which is expected taking into consideration the size of emigration 
flows from this region. The smallest number of remittance receiving households is in the City of Belgrade and South-East Serbia (Table 3).

The high share of remittances in average income does not necessarily mean that remittances substantially contribute to poverty reduction. It would be useful to consider whether poor or exposed to the risk of poverty households receive remittances. Table 4 shows distribution of the remittances receiving households by decile groups of consumption. In the first decile group, there are the households with the smallest consumption while in the tenth decile group there are the households with the largest consumption.

Distribution of remittances receiving households in rural areas between lower and upper decile groups is almost equal. There are 45.6 percent of the households in the lower decile groups from which 10.2 percent belongs to the category of the poorest. From the total number of urban households that receive remittances, 74.1 percent belongs to the upper decile groups from which even 26 percent is among the richest.

Table 4. Distribution of remittance receiving households by decile groups, percent

\begin{tabular}{|c|c|c|c|c|c|}
\hline Decile group & Urban & Rural & West Serbia & Sumadija & East Serbia \\
\hline 1 & 0.9 & 10.2 & 20.7 & 5.9 & 3.9 \\
\hline 2 & 4.6 & 7.1 & 3.4 & 2.0 & 7.8 \\
\hline 3 & 7.4 & 12.6 & 10.3 & 3.9 & 11.8 \\
\hline 4 & 7.4 & 3.9 & 10.3 & - & 3.9 \\
\hline 5 & 5.6 & 11.8 & 10.3 & 7.8 & 7.8 \\
\hline 6 & 9.3 & 8.7 & 10.3 & 7.8 & 7.8 \\
\hline 7 & 10.2 & 6.3 & 10.3 & 11.8 & 5.9 \\
\hline 8 & 12.0 & 15.0 & 6.9 & 27.5 & 13.7 \\
\hline 9 & 16.7 & 13.4 & 13.8 & 11.8 & 17.6 \\
\hline 10 & 25.9 & 11.0 & 3.4 & 21.6 & 19.6 \\
\hline
\end{tabular}

Source: Author's calculation according to LSMS 2007 data

(http://microdata.worldbank.org/index.php/catalog/lsms)

If one compares distribution of households between regions where is the largest share of the remittance receiving households, a certain differences may be noticed. In West Serbia, more than half of the remittances receiving households are in lower decile groups (55 percent). In Sumadija and East Serbia, households that are not exposed to the risk of poverty receive more remittances than others do. In Sumadija, there are only 19.6 percent remittances receiving households in lower 
decile groups. Considerable differences exist in the sense of presence the remittances receiving households in the first decile group. Fifth of remittances receiving households in West Serbia is among the poorest, while in Sumadija and East Serbia share of the households in the first decile group is considerably lower (5.9 percent i.e. 3.9 percent) (Peković, 2013).

\section{Methodology of the Research}

One of methodological issues important for analysis is how to determine the role of remittances in the household consumption. In the given review of empirical literature, there are two possible methodological treatments of remittances. According to one, remittances are potential substitute for earnings the emigrants would realise if they stayed in home country, while in the second case the remittances represent exogenous transfer of money. If remittances are treated as a substitute for domestic earnings, effects of remittances on poverty would be estimated by generating counterfactual household consumption with an absence of migration and remittances. In that case, a hypothetical question would be: What would be the level of household consumption if the members-emigrants of such households stayed and worked in the home country?

First, it is necessary to estimate parameters of household consumption per capita from households which do not receive remittances and have no membersemigrants. In regression, characteristics of the household's members are used as determinants. These parameters were applied to the households which receive remittances for predicting household consumption per capita in excluding remittances situation. All members, including emigrant-workers are considered as regression determinant. Poverty measures are calculated using predicted household consumption in excluding remittances situation. Comparing them with real poverty measures, conclusion on an impact of remittances to poverty is to be made.

If remittances are treated as exogenous transfer of money, there is a question what would be the poverty level if those households did not receive remittances, i.e. an amount of remittances boils down to zero. Household consumption simply decreases for an amount of remittances. Poverty measures calculated according to reduced consumption are compared with real poverty measures. This method application gives a simplified picture of the remittances impact because it does not take into consideration any potential effects of the emigrant's absence (Sobrevinas, 2013).

Choice of the method to some extent depends on available data. The first method proceeds from an assumption that remittances are sent to the households by absent members-emigrants. Using of this method implies to existence of emigrants characteristics data. However, remittances data at the household level in the Republic of Serbia are scarce. Living Standards Measurement Survey was 
conducted on the sample not designated for needs of remittances effects research. One should bear in mind possible disadvantages of using this sample when small groups are in charge as remittances receiving households. Within the LSMS 2007, only 35 households reported emigrants among their members. LSMS data suggests that a significant number of the households receive remittances from the persons who are not the members of the household (relatives, friends) and for them remittances are exogenous transfers of money.

Taking into consideration all stated, the paper used the method according to which remittances are exogenous transfer. This method of research also used Adams (2004, 2006), Olowa (2013) and Sobrevinas (2013).

Consumption as a base for determination of the poverty level will be used due to more reasons. Previously studies showed that the households averagely report smaller income than consumption. The households are more willing to report consumption than their income. Coverage of total income itself may represent a problem because it, except of regular earnings, includes other sources of income such as interest, dividends, rents, income of self-employment which the examinee may overlook or forget to report. Some sources of income are very hard to determine (growth of value of animals or land used in agricultural production). On the other hand, household consumption is relatively stable and less subject to shortterm fluctuations so there is larger possibility that monthly consumption of the household will be representative in relation to income (Haughton \& Khandker, 2009).

Another important issue is related to the manner of remittances use. Assuming that remittances are entirely used for consumption may cause that some households from a higher decile group even in the absence of migration, may belong to the lower decile group after deducting of remittances. That would overestimate the impact of remittances to poverty. On the other hand, there are no data on whether households allocate remittances for savings. For this reason, the remittances receiving households from LSMS are divided in two groups in this study. The first group is made of 158 households whose total consumption is larger that total income. Since the entire income is used for consumption, it is assumed for this group of households that remittances, as one of components of income, are used entirely for consumption. The second group is made of 77 households with total consumption smaller than total income. It is assumed for such households that the share of remittances used for consumption is equal to percentage participation of total consumption in total income. The poverty level is determined based on consumption reduced for remittances share used for consumption. Calculated poverty measures with reduced consumption are compared with real poverty measures.

For estimating remittance effects on poverty, we use the poverty indicators class according to Foster, Greer and Thorbecke (Foster et al., 1984, p. 763). This 
class of indicators is also used in Living Standards Measurement Study Serbia 2002-2007. The most commonly used indicator is the poverty index expressing a part of population who are poor i.e. whose consumption is below absolute poverty line. The poverty indicators in Living Standards Measurement Study Serbia are calculated as follows (Statistical Office of the Republic of Serbia, 2008, p. 180):

$$
P_{\alpha}=\frac{1}{n} \sum_{i=1}^{n}\left[\max \left(\frac{Z-C i}{Z}, 0\right)\right]^{\alpha}
$$

where $\mathrm{Z}$ represents the poverty line, $\mathrm{C} i$ is consumption per consumer unit; $\mathrm{p}$ is total number of persons and $\alpha$ is a parameter. For $\alpha=0, \mathrm{P}(0)$ is the poverty index. However, the poverty index does not take into account the poverty intensity, how much the poor people are poor. In the case of consumption reduction of the poor people, the poverty index remains unchanged. Therefore, we use more sensitive poverty measures that show the gap between consumption of the poor and the poverty line. If $\alpha=1, \mathrm{P}(1)$ is the depth of poverty showing an averaged deficit of consumption as percentage of the poverty line among total population. The poverty severity $\mathrm{P}(2)$, for $\alpha=2$ gives larger weight to the poor who are more distant from the poverty line and measures inequality among the poor.

\section{Results and discussion}

Results presented in Table 5 show that remittances contribute to reduction of all poverty measures. However, excluding of the remittances flow would more impact increasing of depth and severity of poverty than growth of the poverty index. Comparing changes in the poverty measures of urban and rural households, it is possible to conclude that remittances almost equally contribute to reduction of poverty index. If the remittances sending would be stopped, the poverty index in sample of rural households would be increased for 3.63 percent while in urban households the share of poor would be increased for 3.76 percent.

However, the difference in consumption among the poor would be larger in rural households in relation to urban ones. The depth and severity of poverty show a larger growth in rural households and, without remittances, consumption of the poor would be largely distant from the poverty line.

The lack of remittances as the source of income, in different extent would reflect to poverty measures in regions. In East Serbia, the households receive in average the largest amount of remittances. Excluding this income would considerably affect the level of consumption and, without remittances, the poverty index in this region would increase from 10.53 to 11.14 percent. The gap between the poor would also substantially increase. In relation to other regions, poverty measures in East Serbia would have the largest growth. Since East Serbia is one of the poorest regions in 
the Republic of Serbia, inflow of remittances substantially alleviates the poverty level.

Table 5. Poverty measures

\begin{tabular}{|l|c|c|c|c|c|c|}
\hline & \multicolumn{3}{|c|}{ Including remittances } & \multicolumn{3}{c|}{ Excluding remittances } \\
\cline { 2 - 7 } & $\begin{array}{c}\text { Poverty } \\
\text { index }\end{array}$ & $\begin{array}{c}\text { Depth of } \\
\text { poverty }\end{array}$ & $\begin{array}{c}\text { Severity of } \\
\text { poverty }\end{array}$ & $\begin{array}{c}\text { Poverty } \\
\text { index }\end{array}$ & $\begin{array}{c}\text { Depth of } \\
\text { poverty }\end{array}$ & $\begin{array}{c}\text { Severity } \\
\text { of poverty }\end{array}$ \\
\hline Urban & 4.26 & 0.81 & 0.26 & 4.42 & 0.83 & 0.26 \\
\hline Rural & 10.74 & 2.09 & 0.67 & 11.13 & 2.29 & 0.78 \\
\hline $\begin{array}{l}\text { City of } \\
\text { Belgrade }\end{array}$ & 3.04 & 0.52 & 0.15 & 3.04 & 0.52 & 0.15 \\
\hline $\begin{array}{l}\text { Vojvodina } \\
\text { Province }\end{array}$ & 5.40 & 1.15 & 0.43 & 5.84 & 1.26 & 0.47 \\
\hline West Serbia & 8.86 & 1.28 & 0.35 & 9.13 & 1.68 & 0.63 \\
\hline Sumadija & 4.75 & 0.77 & 0.20 & 4.94 & 0.80 & 0.21 \\
\hline East Serbia & 10.53 & 1.40 & 0.45 & 11.14 & 2.20 & 0.69 \\
\hline $\begin{array}{l}\text { South-East } \\
\text { Serbia }\end{array}$ & 14.39 & 3.17 & 1.04 & 14.51 & 3.24 & 1.08 \\
\hline
\end{tabular}

Source: Author's calculation according to LSMS 2007 data

(http://microdata.worldbank.org/index.php/catalog/lsms)

In relation to other high emigration regions, the smallest growth of the poverty index would be realised in West Serbia (3.05 percent). That can be explained with the fact that fifth of the remittances receiving households is already among the poorest. For that reason, excluding of remittances would cause that consumption of those households substantially goes far from the poverty line. The poverty depth in the sample of this region would be larger for 31 percent while the poverty severity would be almost doubled. Among high emigration regions, the smallest changes in the depth and severity of poverty would be seen in Sumadija where remittances do not have so high participation in the household income (16 percent) such as in other regions and the remittances receiving households are mainly among the richest ones.

In addition, we test whether the difference in the status of the poor, the depth and severity of poverty in the situation including remittances comparing with the situation excluding remittances is significant. The results of Paired t-test presented in Table 6 show that this difference is statistically significant among rural households. Excluding remittances as source of income from consumption can caused that some remittance receiving households become poor. Also, the consumption of poor remittance receiving households would be more distant from the poverty line without remittances. However, the difference between poverty measures as remittances effect is not statistically significant among households in 
Sumadija and South-East Serbia. In East Serbia, the inflow of remittances statistically significant reduced only the poverty index.

Table 6. Paired t-test

\begin{tabular}{|l|c|c|c|}
\hline & Poverty index & Depth of poverty & Severity of poverty \\
\hline Urban & $2.24^{* *}$ & $-1.67^{*}$ & -1.25 \\
\hline Rural & $2.72^{* * *}$ & $(-3.50)^{* * *}$ & $-2.75^{* * *}$ \\
\hline City of Belgrade & - & - & - \\
\hline Vojvodina Province & $2.45^{* *}$ & $-2.11^{* *}$ & $-1.85^{*}$ \\
\hline West Serbia & 1.41 & $-2.47^{* *}$ & $-2.09^{* *}$ \\
\hline Sumadija & 1.41 & -1.06 & -1.02 \\
\hline East Serbia & $2.00^{* *}$ & -1.55 & -1.23 \\
\hline South-East Serbia & 1.00 & -1.31 & -1.14 \\
\hline
\end{tabular}

Note: ***, ** and * represent statistical significance at the 1,5 and 10 percent respectively.

Source: Author's calculation

The present results are consistent with the results of previous researches of remittance effects on poverty, being analysed in the first part of the study. Research done by Adams (2004) in Guatemala showed the remittances treated as exogenous transfer of money have a larger impact on reduction of poverty severity in relation to the poverty index. Excluding the remittances from consumption would increase the poverty index for 2.3 percent and the poverty severity for 13.6 percent (Adams, 2004). Gustafsson and Makonnen (1993) found that the poverty index in Lesotho would increase for 26 percent and the poverty severity for 52 percent if consumption were decreased for remittances.

\section{Conclusion}

The establishment of the banking union in Europe is a major step and the most radical reform of the Economic and Monetary Union since the beginning of the global financial crisis. It is not surprising, because of the significant role that the banks in Europe have for the real economy. This reform takes place in the context of a regulatory overhaul of the financial sector on a global scale, affecting the banks in the other centers of the developed world as well.

By counterfactual household consumption in absence of remittances, it is realised that remittances contribute to reduction of all poverty measures. Impact of remittances is larger in decreasing the depth and severity of poverty than to the poverty index. Decreasing consumption for remittances in larger extent would reflect to poverty measures in rural than in urban households. The largest 
percentage growth of poverty measures would be realised in East Serbia, but this growth is not statistically significant for depth and severity of poverty. In West Serbia, remittances more influence the depth of poverty, which would be increased for 31 percent without remittances. The smallest changes in the depth and severity of poverty would be seen in Sumadija.

However, the results should interpreted with caution because of the sample size at the regional level which is not designated for the needs of researching the remittances effect and leads to smaller coverage of remittances receiving households data. As a result, we need more comprehensive researches that would estimate the size of the remittance effects to poverty.

For more comprehensive research, we need more reliable and more complete data on remittances at the household level. Survey data would provide better insight in real size of remittances because they would include also informal flows. International institutions are trying to promote this method of data collection on the migrants' remittances. International Labour Organisation encourages inclusion of the remittance questions into existed Labour Force Survey rather than implementation of specialized surveys. Extended Labour Force Survey has been applied in Armenia and Thailand. The Migration Survey as a special part includes those questions related to characteristics of the persons sending and receiving remittances, the first and the last sending of remittances, remittances receipt frequency during one year, total received amount, if remittances are received from the persons out of the household. Since the size of Diaspora and the remittances inflows in the Republic of Serbia is considerable, improvement of data would provide more efficient managing of remittances and achieving larger effects.

\section{References}

Acharya, P.C. \& Leon-Gonzales, R. (2012). The Impact of Remittance on Poverty and Inequality: A Micro-Simulation Study for Nepal (GRIPS Discussion Paper, No. 1126), Tokyo: National Graduate Institute for Policy Studies.

Acosta, P., Calderon, C., Fajnzylber, P. \& Lopez, J.H. (2008). Do Remittances Lower Poverty Levels in Latin America? In: Fajnzylber, P. \& Lopez, J.H. (Eds.), Remittances and Development Lessons from Latin America (pp. 87-132). Washington: World Bank.

Adams, H.R. (2004). Remittances and Poverty in Guatemala (World Bank Policy Research Working Paper, No. 3418), Washington: World Bank.

Adams, H.R. (2006). Remittances and Poverty in Ghana (World Bank Policy Research Working Paper, No. 34838), Washington: World Bank.

Adams, H.R. \& Page, J. (2005). Do International Migration and Remittances Reduce Poverty in Developing Countries? World Development, 33 (10), 1645-1669.

Bertoli, S. \& Marchetta, F. (2014). Migration, Remittances and Poverty in Ecuador. The Journal of Development Studies, 50 (8), 1067-1089. 
Bouoiyour, J. \& Miftah, A. (2014). The Impact of Migrant Workers' Remittances on The Living Standards of Families in Morocco: A Propensity Score Matching Approach (CATT Working Paper, No. 10), Pau Cedex: University of Pau, CATT.

Brown, P.C.R. \& Jimenez, E. (2008). Estimating the Net Effects of Migration and Remittances on Poverty and Inequality: Comparison of Fiji and Tonga. Journal of International Development, 20 (4), 547-571.

Byase, M. (2012). The relationship between poverty and remittances in South Africa, http://carnegie3.org.za/docs/papers/28_Biyase_The\%20relationship\%20between\%2 0poverty\%20and\%20remittances\%20in\%20South\%20Africa.pdf, Accessed: 12 December 2016.

De Haas, H. (2006). Migration, Remittances and Regional Development in Southern Morocco. Geoforum, 37 (4), 565-580.

Foster, J., Greer, J. \& Thorbecke, E. (1984). A Class of Decomposable Poverty Measures. Econometrica, 52 (3), 761-766.

Gustafsson, B. \& Makonnen, N. (1993). Poverty and Remittances in Lesotho. Journal of African Economies, 2 (1), 49-73.

Haughton, J. \& Khandker, R.S. (2009). Handbook on Poverty and Inequality. Washington: World Bank.

Hoti, E. (2009). Remittances and Poverty in Albania,https://liveatlund.lu.se/intranets/LUSEM/NEK/mfs/MFS/192.pdf, Accessed: 24 February 2012.

Jovicic, M. \& Dragutinovic Mitrovic, R. (2006). Macroeconomic Analysis of Causes and Effects of Remittances: A Panel Model of the SEE Countries and the Case Study of Serbia (The WIIW Balkan Observatory Working Papers, No. 063), Vienna: The Vienna Institute of International Studies.

Olowa, O.W., Awoyemi, T.T., Shittu, M.A. \& Olowa, O.A. (2013). Effects of Remittances on Poverty among Rural Households in Nigeria. European Journal of Sustainable Development, 2 (4), 263-284.

Page, J. \& Plaza, S. (2006). Migration Remittances and Development: A Review of Global Evidence. Journal of African Economies, 00 (2), 245-336.

Pejin-Stokic, Lj. \& Grecic, V. (2012). Social Impact of Emigration and Rural-Urban Migration in Central and Eastern Europe: Final Country Report: Serbia. Brussels: European Commission, DG Employment, Social Affairs and Inclusion.

Peković, D. (2013). Doznake kao faktor smanjenja ruralnog siromaštva u Srbiji. U: Jovanović Gavrilović, B., Rakonjac-Antić, T., Stojanović, Ž. \& Filipović, M. (Eds.), Tematski zbornik radova Ekonomska politika i razvoj (pp. 107-128). Beograd: Ekonomski fakultet.

Petree, J. \& Baruah, N. (2007). A Study of Migrant-Sending Households in Serbia Receiving Remittances from Switzerland (IOM Migration Research Series, No. 28), Geneva: IOM.

Rivera, M.J. (2005). The Impact of Migration and Remittances on Distribution and Sources Income: the Mexican Rural Case (UN/POP/MIG/2005/06), New York: United Nations.

Sobrevinas, B.A. (2013). Migration, Remittances and Poverty: Evidence from the Community-Based Monitoring System (CBMS) Data in Selected Communities in the Philippines,

http://gfa.hof.uni-frankfurt.de/arno/ArnoXI/Papers/Sobrevi\%C3\%B1as.pdf 
Accessed: 24 May 2014.

Statistical Office of the Republic of Serbia (2008). Living Standard Measurement Study: Serbia 2002-2007. Belgrade: Statistical Office of the Republic of Serbia Publishing.

Suki, L. (2006). Remittances in Serbia and Financial Sector Development: Business Opportunities and Priorities for Investment. New York: the Earth Institute at Columbia University.

Taylor, J.E., Adams, R., Mora, J. \& Lopez-Feldman, A. (2005). Remittances, Inequality and Poverty: Evidence from Rural Mexico (AAEA Working Paper, No. 05-003), Milwaukee: American Agricultural Economics Association.

UNCTAD (2011). Impact of Remittances on Poverty in Developing Countries.Geneva: UNCTAD Publishing.

World Bank (2011). Migration and Remittances Factbook 2011. Washington: World Bank Publishing.

\section{EFEKTI DOZNAKA IZ INOSTRANSTVA NA RURALNO I REGIONALNO SIROMAS̆TVO U REPUBLICI SRBIJI}

Apstrakt: U radu se istražuje uticaj doznaka iz inostranstva na ublažavanje siromaštva ruralnih domaćinstava i regiona u kojima je prisutno visoko učešce emigranata među stanovništvom. Doznake predstavljaju značajan deo dodatnog dohotka domaćinstava koji se najčešće koristi za potrošnju i unapređenje životnog standarda. Koristeći podatke Ankete o životnom standardu iz 2007. godine ocenjuje se uticaj doznaka na indeks siromaštva, dubinu i oštrinu siromaštva u Republici Srbiji. Usled ograničenosti podataka vrši se simulacija potrošnje domaćinstava u uslovima odsustva doznaka pri čemu se one tretiraju kao egzogeni transfer novca. Rezultati pokazuju da doznake imaju veći uticaj na siromaštvo ruralnih domaćinstava posebno na dubinu i oštrinu siromaštva. Posmatrano prema regionima, doznake imaju najveći uticaj na nivo siromaštva u Istočnoj Srbiji, dok efekti na dubinu i oštrinu siromaštva nisu statistički značajni. Najmanje promene u dubini i oštrini siromaštva prisutne su u Šumadiji.

Ključne reči: migracije, doznake, siromaštvo, Republika Srbija.

\section{Author's biography}

Drinka Pekovic was born in 1980 in Novi Sad. She graduated from the Faculty of Economics in Subotica in 2004. She holds a master's degree in fiscal and monetary management and social infrastructure management from Faculty of Economics, University of Belgrade. Currently, she is a $\mathrm{PhD}$ candidate at the Faculty of Economics, University of Belgrade. After graduating, Drinka Pekovic has started to work as teaching assistant at Higher School of Professional Business Studies in Novi Sad. In 2011, she became a lecturer in field of economic theory and policy. 